\title{
TINJAUAN YURIDIS TERHADAP TINDAK PIDANA PENCEMARAN NAMA BAIK DALAM KITAB UNDANG-UNDANG HUKUM PIDANA DAN UNDANG-UNDANG NOMOR 11 TAHUN 2008 TENTANG INFORMASI DAN TRANSAKSI ELEKTRONIK
}

\author{
Oleh \\ Ahmad Royani \\ Dosen Fakultas Hukum Universitas Islam Lamongan
}

\begin{abstract}
ABSTRAK
Jurnal ini berjudul tinjauan yuridis terhadap tindak pidana pencemaran nama baik dalam kitab undang undang hukum pidana dan undang-undang nomor 11 tahun 2008 tentang informasi dan transaksi elektronik Latar belakang jurnal ini diawali dengan pertanyaan-pertanyaan mengenai pertama, kategori pencemaran nama baik dalam kitab undang-undang hukum pidana dan undang-undang nomor 11 tahun 2008 tentang inforasi dan transaksi elektronik yang menimbulkan pro dan kontra atas penerapan undang-undang nomor 11 tahun 2008 tentang informasi dan transaksi dalam kehidupan masyarakat.

Kedua, sanksi atau akibat hukum yang diterapkan terhadap pelaku tindak pidana elektronik khususnya pencemaran nama baik. Untuk masalah pertama dari penelitian sebenarnya secara norma pencemaran nama baik di KUHP itu sama dengan apa yang ada dalam UU ITE, namun bila dilihat dari ancamanya akan nampak perbedaanya. Untuk permasalahan yang kedua mengingat asas lex specialis lex generalis apabila kejahatan dilakukan melalui media internet penerapan pasal 27 ayat (3) UU ITE harus didahulukan mengingat bahwa undangundang nomor 11 tahun 2008 tentang informasi dan transaksi elektronik merupakan peraturan khusus tapi tanpa mengesampingkan kitab undang-undang hukum pidana (KUHP) karena keduanya saling melengkapi, hal itu dilakukan karena dalam undang-undang nomor 11 tahun 2008 tentang informasi dan transaksi elektronik tidak menjelaskan secara rinci tentang kategori pencemaran nama baik. Untuk bentuk dan jenis pencemaran nama baik bisa melihat buku II bab XVI kitab undang-undang hukum pidana, tetapi untuk penerapan ancamanya secara concrit menggunakan undang-undang nomor 11 tahun 2008 tentang informasi dan transaksi elektronik.
\end{abstract}

Kata kunci: tindak pidana, pencemaran nama baik melalui media informasi dan transaksi elektronik.

\section{A. Pendahuluan}

\section{Latar belakang}

Salah satu dari permulaan perkembangan informasi dan transaksi elektronik yaitu diciptakanya masyarakat sosial,kenapa masyarakat dikatakan masyarakat sosial karena kehidupan kehidupan manusia yang saling membutuhkan dan tidak lepas dari masyarakat di sekitarnya.

Masyarakat memanfaatkan informasi dan transaksi elektronik agar mudah untuk melakuakan semua hal dalam bentuk informasi dan transaksi elektronik,

diantara faktor positif dari perkembangan informasi dan transaksi elektronikadalah luasnya pembelajaran dan potensi pendidikan, mengetahui sistem jalanya pemerintahan, dan bahkan bisa sebagai curahan isi hati.

Perkembangan internet di era globalisasi ini mencapai tahap yang begitu cepat, sehingga banyaknya tempat yang menyediakan layanan internet seperti hostpot,wifi dan lain-lain. 
Canggihya media sosial yang lebih di kenal dengan sebutan (medsos) semakin memudahkan kita untuk mengakses segala informasi yang kita inginkan, dari yang jauh menjadi dekat.

Menyebar luasnya internet di seluruh dunia seperti pemerintah, ekonomi, dan pendidikan. banyaknya anak kecil yang sudah menghilangkan masa kecilnya dengan permainan tradisional berubah menjadi gadget.

Penggunaan media sosisl sering kali di gunakan untuk melakuakan kejahatan, Semua manfaat positif dan negatifnya tergantung pada pengguna, penyedia layanan internet hanya menyediakan dengan tujuan memudahkan pengguna baik dalam pekerjaan maupun aktifitas lainya.

Bangsa indonesia tumbuh dan berkembang menuju masyarakat industri tehnologi dan informasi. Meskipun sebenarnya dalam tehnik informasi ada beberapa hal yang masih tertinggal, salah satu penyebabnya yaitu ketidak mampuan dalam mengatasi masalah hukum, yang mengakibatkan terjadinya tindak pidana melalui media internet.

Tanggal 21 april 2008 telah diundangkan undang-undang omor 11 tahun 2008 tentang informasi dan transaksi elektronik (ITE). Undang-undang ini dibuat dengan tujuan dapat dilakukan secara optimal,merata dan menyebar ke seluruh masyarakat guna mencerdaskan kehidupan bangsa.Perubahan kehidupan dalam masyarakat dalam berbagai bidang secara lansung akan mempengarui lahirnya bentuk-bentuk dari perbuatan hukum baru.

Tindak pidana informasi dan transaksi elektronik diatur dalam 9 pasal dari pasal 27 sampai dengan pasal 35, dalam 9 pasal tersebut menjelaskan tindak pidana dibidang informasi dan transaksi elektronik (ITE).

Disini penulis hanya menerangkan tentang tindak pidana pencemaran nama baik dalam pasal 27 ayat (3).

Tindakann pencemaran nama baik atau fitnah menjadi salah satu kejahatan yang sering di lakukan baik melalui media elektronik maupun media masa.

Karena perumusan dalam pasal 27 ayat (3) undang-undang no 11 tahun 2008 tentang informasi dan transaksi (ITE) sangatlah sederhana maka dalam penanganan masalah tindak pidana penceemaran nama baik ini merujuk kepada undang-undang nomor 8 tahun 1981 yang secara rinci menjelaskan tentang kategori kejahatan yang ada, begitupun terhadap ancaman pidanya kitab undang-undang hukum pidana merumuskan dengan sesuai dengan kejahatan yang dilakukan, gunanya supaya terciptanya keadilan.

Selain ganti rugi yang di berikan, bisa juga hukuman pidana diharapakan kepeda pihak yang melakukan tindak pidana pencemaran nama baik, dalam KUHP di jelaskan 16 pasal yang mengatur tentang penghinaan.

Pasal 310 kitab undang-undang hukum pidana “

(1) Barang siapa sengaja menyerang kehormatan atau nama baik seseorang dengan menuduhkan sesuatu hal,yang maksudnya terang supaya hal itu diketahi umum, diancam karena pencemaran dengan pidana penjara paling lama sembilan bulan atau denda paling banyak empat ribu lima ratus rupiah.

(2) Jika hal itu dilakukan dengan tulisan atau gambaran yang disiarkan,pertunjukan atau di tempelkan di muka umum, maka di ancam karena pencemaran tertulis dengan pidana penjara paling lama satu tahun empat bulan atau pidana denda paling bayak empat ribu lima raus rupiah.

(3) Tidak merupakan pencemaran atau pencemaran tertulis, jelas perbuatan jelas dilakukan demi kepentingan umum atau karena terpaksa untuk membela diri.

tetapi setelah di sahkanya pasal 27 ayat 3 undang-undang nomor 11 tahun 
2008 tentang imformasi dan transaksi elektronik menjelaskan " setiap orang dengan sengaja dan tanpa hak mendistribusikan dan/atau dokumen elektronik yang memiliki muatan penghinaan dan/atau pencemaran nama baik."ketentuan pidana yang di jelaskn dalam bab XI pasal 45 ayat 1 "setiap orang memenuhi unsur sebagaimana di maksud dalam pasal 27 ayat (1),ayat (2), ayat (3), atau ayat (4) dipidana dengan pidana penjara paling lama 6 (enam) tahun dan/atau denda paling banyak Rp.1.000.000.000.00 ( satu miliar rupiah).

Yang menimbulkan pro dan kontra yang berkaitan dengan penerapan hukum jika terjadi tindak pidana pencemaran nama baik, penulis hanya membahas tentang perbedaan konsep pencemaran nama baik dan akibat dari penggunaan tindak pidana elektronik menurut KUHP pasal 310dan pasal 27 ayat (3) undangundang informasi dan transaksi elektonik.

Mengingat azaz lex specialis derogat legi generalis mengandung makna bahwa aturan hukum khusus akan mengesampingkan aturan hukum yang umum, oleh karena itu aturan yang mengatur dalam undang-undang nomor 11 tahun 2008 tentang informasi dan transaksi elektronik mengesampingkan dalam aturan yang mengatur di kittab undangundang hukum pidana.

Tetapi munculya ketidak adilanantara undang-undang informasi dan transaksi elektronikyang mengatur tentang hukuman yang di jatuhkan oleh pelaku tindak pidan, dengan konsep yang di atur dalam kitab bab XVI buku kedua tentang kejahatan undang-undang hukum pidana.

Implentasi yang di alami dalam penggunaan undang-undang nomor 11 tahun 2008 tentang informasi dan transaksi elektronik itulah yang menjadikan perdebatan atau pro dan kontra di masyarakat.

\section{Kajian pustaka}

Suatu perbuatan dapat dikatakan sebagai pencemaran nama baik masih tidak jelas, karena masih banyak faktor yang harus di mengerti dan di pelajari.

Adanya hubungan antara nama baik dan kehormatan dalam hal ini dapat di artikan masing-masing. Nama baik adalah penilaian baik dari anggapan umum, kepribadian atau perilaku seseorang yang dilihat dari segi moralnya. Dan penilaian dipandang dari sudut masyarakat umum. Sedangkan kehormatan adalah perasaan terhormat seseorang dimata masyarakat.

Oleh karena itu, penyerangan salah satu antara nama baik ataupun kehormatan dapat di jadikan alasan menuduh bahwa orang itu melakukan penghinaan.

Seseorang akan tersinggung jika kehormatannya di serang, prasaan tersinggung atau tidak dapat ditinjau dengan perbuatan tertentu misalkan seseorang yang gila tau anak kecil yang tidak tau apa-apa tidak akan tersinggung jika kehormatanya di serang.

Pencemaran nama baik adalah perbuatan yang dilakukan dengan cara menyerang kehormatan dan nama baik seseorang yang menyebabkan kerugian terhadap orang yang merasa harga diri dan nama baiknya diserang.

Menurut Pasal 310 kitab undang-undang hukum pidana " dijelaskan tentag pengertia pencemaran nama baik:

(1)Barang siapa sengaja menyerang kehormatan atau nama baik seseorang dengan menuduhkan sesuatu hal,yang maksudnya terang supaya hal itu diketahi umum, diancam karena pencemaran dengan pidana penjara paling lama sembilan bulan atau denda paling banyak empat ribu lima ratus rupiah.

\section{Tujuan penelitian}

Tujuan yang hendak dicapai dalam penelitian ini adalah sebagai berikut : 
1. Untuk mengetahui kategori dari pencemaran nama baik antara undang-undang 11 tahun 2008 tantang informasi, dan transaksi elektronik dan kutab undang-undang hukum pidana (KUHP) .

2. Untuk mengetahui akibat dari penggunaanpasal 27 ayat 3 dan penerapan pasal 45 ayat (1) undang-undang 11 tahun 2008 tantang informasi dan transaksi elektronik,terhadap pasal 310 kitab undang-undang hukum pidana (KUHP).

\section{B. Metode penelitian}

Penulis menggunakan metode penelitian yuridis normatif dengan cara pengumpulan data dari kepustakaan.

\section{Hasil Penulisan dan pembahasan}

Kategori penghinaan dalam kitab undang-undang hukum pidana (KUHP)

1. Pencemaran pasal (310 KUHP)

2. Fitnah pasal (311KUHP)

3. Penghinaan ringan pasal KUHP)

4. Pengaduan fitnah pasal (317 KUHP)

5. Menimbulkan persangkaan pasal (318 KUHP)

6. Pencemaran terhadap orang yang sudah meninggal pasal (320-321 KUHP)

Penerapan sanksi dalam kasus ini menggunakan undang-undang nomor 11 tahun 2008 tentang informasi dan transaks elektronik tapi tanpa mengesampingkan pasal 310 kitab undang-undang hukum pidana (KUHP).

Dalam pasal 45 ayat (1) undangundang informasi dan transaksi elektronik (ITE)

"Setiap orang yang memenuhi unsur yang di maksud dalam pasal 27 ayat 1 , ayat 2 , ayat 3 , ayat 4 dipidana dengan pidana penjara paling lama 6 (enam) tahun dan/atau denda paling banyak 1000.000.000.00 (satu miliar rupiah)"
Pasal 310 kitab undang-undang hukum pidana “

(1) Barang siapa sengaja menyerang kehormatan atau nama baik seseorang dengan menuduhkan sesuatu hal,yang maksudnya terang supaya hal itu diketahi umum, diancam karena pencemaran dengan pidana penjara paling lama sembilan bulan atau denda paling banyak empat ribu lima ratus rupiah.

(2) Jika hal itu dilakukan dengan tulisan atau gambaran yang disiarkan,pertunjukan atau di tempelkan di muka umum, maka di ancam karena pencemaran tertulis dengan pidana penjara paling lama satu tahun empat bulan atau pidana denda paling bayak empat ribu lima raus rupiah.

\section{Penutup}

\section{Kesimpulan}

a. Menurut Pasal 27 ayat (3) Undangundang nomor 11 tahun 2008 mengatur kejahatan pencemaran nama baik, tapi dalam perincian jenis, bentuk dan ancaman tidak seperti dalam Buku II(KUHP).

Pencemaran nama baik adalah perbuatan yang dilakukan dengan cara menyerang kehormatan dan nama baik seseorang yang menyebabkan kerugian terhadap orang yang merasa harga diri dan nama baiknya diserang.

Dirumuskan dalam pasal 27 ayat (3)

"setiap orang dengan sengaja dan tanpa hak mendistribusikan dan/atau mentransmisikan dan/atau membuat dapat di aksesnya informasi elektronik dan/atau dokumen elektronik yang memiliki muatan penghinaan dan/atau pencemaran nama baik"

Kategori penghinaan dalam kitab undang-undang hukum pidana (KUHP)

1. Pencemaran pasal (310 KUHP)

2. Fitnah pasal (311KUHP) 
3. Penghinaan ringan pasal (315 KUHP)

4. Pengaduan fitnah pasal KUHP)

5. Menimbulkan persangkaan pasal (318 KUHP)

6. Pencemaran terhadap orang yang sudah meninggal pasal (320-321 KUHP)

b. Setiap orang yang melakukan tindak pidana maka akan diminta pertanggung jawabanya tidak terkecuali dalam tindak pidana elektronik, tindak pidana elektronik adalah suatu perbuatan yang oleh undangundang telah dilarang dan di lakukan melalui mesia massa.

Dalam pasal 45 ayat (1) undang-undang informasi dan transaksi elektronik (ITE)

"Setiap orang yang memenuhi unsur yang di maksud dalam pasal 27 ayat 1 , ayat 2 , ayat 3 , ayat 4 dipidana dengan pidana penjara paling lama 6 (enam) tahun dan/atau denda paling banyak 1000.000.000.00 (satu miliar rupiah)"

$$
\text { Pasal } 310 \text { ayat (2) tentang }
$$

pencemaran tertulis

"Jika hal itu dilakukan dengan tulisan atau gambaran yang di siarkan, dipertunjukkan atau ditempelkan dimuka umum maka yang bersalah, karena pencemaran tertulis, diancam pidana penjara paling lama empat bulan atau denda paling banyak tiga ratus rupiah."

Tidak adanya unsur keadilan atas ancaman yang ada Dalam pasal 45 ayat (1) undangundang informasi dan transaksi elektronik (ITE) tanpa diketahui unsur dari pencemaran yang dilakukan seperti yang dijelaskan dalam kitab undang-undang hukum pidan. Inilah yang menjadi pro dan kontra dalam masyarakat umumnya.

\section{c. Saran}

Adapun rumusan rumusan yang diusulkan penulis atas dasar pemikiran yang didapat selama penulisan:

1. Mengingat kita adalah masyarakat sosial yang tidak bisa hidup sendiri maka kita semua perlu untuk menghormati satu dengan yang lainya.

2. Karena tidak ada terperincinya bentuk dan jenis kejahatan pencemaran nama baik maka menurut saya perlu ditambahkan dalam pasal 27 ayat (3) undangundang nomor 11 tahun 2008 tentang informasi dan transaksi elektronik dengan dicantumkan jenis atau bentuk pencemaran nama baik dan ancaman yang ada harus sesuai,agar terciptanya unsur keadilan.

\section{E. Daftar pustaka}

peter mahmud Marzuki, penelitian hukum, universitas air langga.surabaya.

Drs.Adami Chazawi,S.H.,Ardi Ferdian,S.H., M.Kn.,tindak pidana informasi dan transaksi elektronik.Penerbit Media Nusa Creative.Malang

Prof. Dr.hj.mulyati pawennei,S.H,. M.H.,Rahmanuddin tomalili,S.H.,M.H.,hukum pidana.penerbit mitra wacana media,2005.jakarta

Kitab undang-undang hukum pidana

Undang-undang nomor 11 tahun 2008 tentang informasi dan transaksi elektronik

http://sigitpriambodo.blogspot.co.i d/2013/04/makalah-skripsi-tindakpidana.html?m=1 http://glorypentacostal.blogspot.co.id/2011/11/ $\mathrm{v}-$

behaviorurldefaultvmlo.html?m=1 http://indrasatya.blogspot.co.id/2015/04/implikas i-atau-dampakditerapkanya.html?m=1 